\title{
Suggestions from the academic staff for improving the organizational climate of agricultural university
}

\author{
R.P. KADAM ${ }^{1 *}$, S.M. UMATE ${ }^{2}$, G.S. PAWAR ${ }^{2}$ AND R.D. NAWALE ${ }^{3}$ \\ ${ }^{2}$ Seed Technology Research Unit (BSP Unit and VNMKV) PARBHANI (M.S.) INDIA \\ ${ }^{3}$ Department of Extension Education, College of Agriculture, Vasantrao Naik Marathwada Krishi \\ Vidyapeeth, PARBHANI (M.S.) INDIA
}

\begin{abstract}
The present study was conducted in Marathwada region of Maharashtra state. The Vasantrao Naik Marathwada Krishi Vidyapeeth, Parbhani was purposively selected for the study as one of the Agricultural University of Maharashtra State having integrated functioning of teaching, research and extension. 100 respondents selected from the various faculties of Vasantrao Naik Marathwada Krishi Vidyapeeth, Parbhani on the basis of their involvement. Data collected through the questionnaire and data (result) were tabulated and analyzed to know the personal and professional profiles of the academic staff. It was observed that more than half respondents had medium age group (53\%) ranging in 38 to 53 years, 55 per cent were educated upto Ph.D. degree level, 55 per cent were Assistant Professor, 58 per cent having medium service experience, 76 per cent of respondents were male, 66 per cent belonged to open category, 58 per cent belongs to rural background, 68 per cent were from medium income group, 76 per cent were in medium category of job satisfaction group, 39 per cent were of medium level achievement motivation. Suggestions were invited from the academic staff for improving the organizational climate, less than half $(44.00 \%)$ of the respondent suggested that presently working staff position (Academic, research and extension) is very poor, it need urgently all positions are filled. Followed, less than one fourth of the respondents $(21.00 \%)$ were suggested that encourage to academic staff by authority to participate in the international conference / symposium abroad.
\end{abstract}

KeY Words : Suggestions, Organizational climate, Profile, Academic staff

View Point Article : Kadam, R.P., Umate, S.M., Pawar, G.S. and Nawale, R.D. (2014). Suggestions from the academic staff for improving the organizational climate of agricultural university. Internat. J. Home. Sci. Extn. \& Comm. Mgmt., 1 (2): 87-90.

Article History : Received : 01.05.2014; Revised : 17.05.2014; Accepted : 01.06.2014

\footnotetext{
*Author for correspondence

${ }^{1}$ Department of Extension Education, Vasantrao Naik Marathwada Krishi Vidyapeeth, PARBHANI (M.S.) INDIA
} 